ERC Working Papers in Economics 12/11

December/ 2012

\title{
Management-Employee Relations, Firm Size and Job Satisfaction
}

\author{
Aysit Tansel \\ Department of Economics Middle East Technical University \\ 06531 Ankara, Turkey \\ E-mail: atansel@metu.edu.tr \\ Phone:+(90) 3122102057 \\ and \\ Institute for the Study of Labor (IZA), Bonn, Germany \\ and \\ Economic Research Forum (ERF) Cairo, Egypt
}

\author{
Saziye Gazioglu \\ Department of Economics and Instituted of Applied Mathematics (IAM) \\ Middle East Technical University \\ 06531 Ankara, Turkey \\ E-mail: drs.gazioglu@abdn.ac.uk \\ Phone. +(90) 3122106021 \\ and \\ Department of EconomicsUniversity of Aberdeen \\ Aberdeen AB24 3HQ,UK
}




\title{
Management-Employee Relations, Firm Size and Job Satisfaction
}

\author{
Aysit Tansel \\ Department of Economics Middle East Technical University \\ 06531 Ankara, Turkey \\ Institute for the Study of Labor (IZA), Bonn, Germany \\ Economic Research Forum (ERF) Cairo, Egypt \\ e-mail: atansel @metu.edu.tr \\ Telephone: 903122102057 \\ Fax: 903122107964 \\ and \\ Saziye Gazioglu \\ Department of Economics and Instituted of Applied Mathematics (IAM) \\ Middle East Technical University \\ 06531 Ankara, Turkey \\ e-mail: drs.gazioglu@abdn.ac.uk \\ Telephone: 903122106021 \\ Fax: 903122107964 \\ and \\ Department of EconomicsUniversity of Aberdeen \\ Aberdeen AB24 3HQ,UK
}

23 December, 2012

\begin{abstract}
:
This paper investigates the job satisfaction in relation to managerial attitudes towards employees and firm size using the linked employer-employee survey results in Britain.We first investigate the managementemployee relationships and the firm size using maximum likelihood probit estimation . Next various measues of job satisfaction are related to the management-employee relations via maximum likelihood ordered probit estimates. Four measures of job satisfaction that have not been used often are considered. They are satisfaction with influence over job; satisfaction with amount of pay; satisfaction with sense of achievement and satisfaction with respect from supervisors. Main findings indicate that managementemployee relationships are less satisfactory in the large firms than in the small firms. Job satisfaction levels are lower in large firms. Less satisfactory management-employee relationships in the large firms may be a major source of the observed lower level of job satisfaction in them. These results have important policy implications from the point of view of the firm management while achieving the aims of their organizations in particular in the large firms in the area of management-employee relationships. Improving the management-employee relations in large firms will increase employee satisfaction in many respects as well as increase productivity and reduce turnover. The nature of the management-employee relations with firm size and job satisfaction has not been investigated before.
\end{abstract}

Keywords : Job Satisfaction, Managerial Attitudes,Firm size, Linked Employer-Employee data, Britain

JEL Codes: J28, J5, J21, D23 


\section{Introduction:}

This paper investigates the job satisfaction in relation to managerial attitudes towards employees and firm size. A good management-employee relationship is necessary for the satisfactory organization and performance of any firm and for the employees to feel engaged. Autonomy of the employees in their work domain versus hierarchical control by the management towards the aims of the firm should in balance. This can affect the productivity and loyalty of the workers. For this reason the management-employee relations are important. The exploration of this issue is the aim and one of the contributions of this paper.

In any organization the main managerial activities consist of supervision, coordination and task allocation in order to achieve the aims of the organization. This is referred to as organizational structure which is a matter of choice. In today's post-industrial organizational structures the role of the managers are important in the success of the organization. The organizational structure is important for effectiveness and efficiency. In some organizational structures the opinions and the needs of employees are given much attention. In this study we use a survey result where employees are asked questions about the extent of their views in shaping the structure of the organization they work in. Such questions are used to determine the nature of the management-employee relations.

We contribute to the literature in two respects. First, to our knowledge the nature of the managementemployee relations with firm size and job satisfaction has not been studied before. We use a unique data set from Britain on employees matched with employer information. Our second contribution is that we consider four indicators of job satisfaction available in this data set which is discussed later. Job satisfaction with pay 
has been extensively used in the literature. However, the other three indicators of job satisfaction included in this paper are not used in the literature except in a former study by Gazioglu and Tansel (2006).

Locke (1976) defines job satisfaction as individuals' subjective valuation of different aspects of their job. Higher job satisfaction may be due to improvements in the objective aspects of the job either because of reduced expectations or because dissatisfying aspects of the job are downplayed while pleasing aspects are given greater weight. The relationship of job satisfaction to productivity, quit and absenteeism in the work place is emphasized by a number of authors. Iaffaldano and Muchinsky (1985) consider job satisfaction, productivity and job performance. Freeman (1978), Akerlof et al.(1988) and Clark et al. (1998) and more recently Kristensen and Westgard-Nielsen (2004) and Levy-Garbous et al. (2007) indicate that job satisfaction is as good a predictor of quits and absenteeism as wages are. They point out that individuals leave low-satisfaction jobs for high-satisfaction-jobs. Thus, job satisfaction gives useful information about job turnover also. For these reasons it is important to study the various aspects of job satisfaction. Different aspects of job satisfaction which are studied in the literature include gender (Clark, 1997), age (Clark et al. 1996), wage growth (Clark 1999), comparison income and unemployment (Clark and Oswald, 1994; 1996), employment size and work environment (Idson, 1990), job matching (Belfield and Harris, 2002) and service sector (Brown and McIntosh, 2003).

Recently, there have been several studies on the relationship between the firm size and job satisfaction of employees. Scherer's (1976) work was one of the earliest studies in this area. Using 1973 Quality of Employment Survey (QES), he found that low levels of job satisfaction were associated with large firms. Since then other studies such as Stafford (1980), Kwoka (1980) and Idson (1990) gave credence to this result. Kwoka used 1977 QES data and multivariate estimation techniques. Idson (1990) also used 1977 QES survey and examined the relationship between the firm size, work structure and job satisfaction. He 
found that regimentation in the work environment of the larger firms leads to lower levels of job satisfaction. Studies by Dunn $(1980,1986)$ also indicated less worker satisfaction in larger firms [1]. Association of lower levels of job satisfaction with larger firm sizes was also reported in Britain (Clark, 1996). However, a more recent study (Marlow et al. 2004) reports the results of a survey which rejects the negative relationship between job satisfaction and the firm size. Most of the studies on job satisfaction are concentrated on Britain or the USA. However recently there is evidence from other countries as well. Linz (2003) in Russia, Hinks (2009) in South Africa and Drydakis (2010) in Greece investigated various aspects of job satisfaction. One of the earlier studies is by Hamermesh (1977) who studies economic aspects of job satisfaction using a model of occupational choice with job satisfaction data. More recent studies include Hamermesh (2000), Bender \& Sloane (1998), Yousef (1998), Sloane \& Ward (2001), Bender \& Haywood (2003), Uppal (2005), Bockerman and Ilmakunnas (2006) and Haile (2009). Gazioglu and Tansel (2006) and Clark (1996) used British data from WERS and BHPP sources respectively and investigated job satisfaction with various individual and firm characteristics. However, the previous studies did not investigate the quality of management-employee relations, firm size and job satisfaction which is considered in the present paper.

Our main conclusions are the following:, Management-employee relationships are less satisfactory in the large firms than in the small firms. We also observe lower levels of job satisfaction in large firms. Less satisfactory management-employee relationships in the large firms may be a major source of the observed lower level of job satisfaction in them. These results have important policy implications from the point of view of the firm management while achieving the aims of their organizations. Improving the managementemployee relations in large firms will increase employee satisfaction in many respects as well as increase productivity and reduce turnover. 
We organize the paper in the following manner. The data and the variables are presented in Section 2. In Section 3 we investigate the management-employee relationships and the firm size. In Section 4, various measures of job satisfaction are related to the management-employee relations. A discussion of the main covariates used in estimations is provided in Section 5. Concluding remarks are presented in Section 6.

\section{The Data and Variables}

This study uses the data from the 1997 Workplace Employee Relations Survey (WERS), of the Department of Trade and Industry in Britain. WERS is a nationally representative survey including 28,240 employees in over 3000 establishments of 15.8 million workers representing three-quarters of all employees in Britain. In this data set the number of observations is larger and it includes larger size firms than in the previous studies (see Clark 1996;1997). This unique data includes a matched Employer-Employee survey and a rich set of questions on work conditions and management-employee relations. Rose (2000) has discussed the nature of this survey and the nature of related questions in studying job satisfaction. Rose (2005) points out several conceptualization and measurement issues in job satisfaction in this survey.

There are four measures of job satisfaction. They are the satisfaction with influence over job, with amount of pay, with sense of achievement and with respect from supervisors.Each of these four measures are recorded as five category ordered measure with the following values: one corresponds to "very dissatisfied", two to "dissatisfied", three to "neither satisfied nor dissatisfied", four to "satisfied" and five to "very satisfied". The distributions of each of the satisfaction measures are given in Table 1 of Gazioglu and Tansel (2006). The most common (mode) response is the "satisfied" category in all measures except for the satisfaction with pay measure where nearly 41 percent of the employees are either "dissatisfied" or "very dissatisfied". At the other tail, while those who are "very satisfied" with

their pay is only 3.5 percent while this is about 11-15 percent for all other measures of job 
satisfaction.As a result we can conclude that Bristish employees are less satisfied with their pay but are more satisfied by other measures of job satisfaction.

Firm size is measured as the number of the employees at the firm. In Table 1 we provide the means for job satisfaction for five different categories of the firm size. We observe in this table that percentages those who are "satisfied" or "very satisfied" with their influence over their job and with their sence of achievement and with respect from supervisors decrease consistently as the firm size increases from less than 25 employees to 500 or more employees. For instance the proportion of those who are very satisfied with their influence over job decraese from 14 percent for firms with less than 25 employees to 10 percent for firms with 500 or more employees. In contrast the proportion of those who are satisfied or very satisfied with pay stays around the same as the firm size increases. As a result we can say that employees are less satisfied in large firms. In order to investigate the effect of the firm size in relation to mangement-employee relations and in relation to job satisfaction we introduce the logarithm of the firm size in all estimations.

[Table 1 about here]

The Table 1 also gives the means for the cross-tabulation of four measurs of job satisfaction with various aspects of the management-employee relations. As remarked earlier the proportion of who are "satisfied" or "very satisfied" with pay are much smaller than those who are "satisfied" or "very satisfied" by other measures of job satisfaction. For instance, among those who discussed their training needs with their managers (during the past year) 13 percent are "very satisfied" with their influence over job. Simiar figures are 3.5 percent for satisfaction with pay, 16 percent for satisfaction with sense of achievement and 17 percent for satisfaction with respect from supervisors. The similar proportions of those who are "satisfied" are 51, 34, 52 and 49 respectively. To look at another example among those 
who say that managers are very good at treating employees fairly, 31, 11, 38, 49 percents are "very satisfied" with influence over job, with pay, with sence of achievement and with respect from supervisors respectively. The similar proportions of those who are "satisfied" are 54, 46, 49 and 42 percents respectively.

The other variables in the tables are described as follows. Male takes avalue of 1 and female is the base category. Age is measured continuosly in years. With regards to education variables, degree or postgraduate holders take the value of one and zero otherwise. The A-O -level holders atake the value of 1 and zero otherwise.The married ones are those who are living with a spouse or a partner and takes the value of one. The base category of singles include singles, widows, divorsees and separated.

There are two main equations estimated in this paper. The first set of equations estimated are presented in Tables 2 and 3. In these tables various indicators of management-employee relations(which are the dependent variables) are related to the firm size and a set of control variables. These equations are probit equations and estimated by maximum likelihood method. Only a small set of the control variables are reported in these tables. The full set are available in Gazioglu and Tansel (2012). The second set of equations estimated are presented in Tables 4 and $5 . \quad$ In these tables various measures of job satisfaction (which are the dependent variables with five ordered categories) are related to firm size and various control variables which include employee characteristics, firm characteristics and industry characteristics. These equations are ordered probit equations and are estimated by maximum likel,ihood method. The equations in Table 4 does not include variable on management-employer relations while the equations in Table 5 include these variables as further explanatory variable. Only a small set of the control variables are reported in Tables 4 and 5 for brevity. The full set of estimates are available in Gazioglu and Tansel (2006) 


\section{Management-Employee Relations and Firm size}

In this section we investigate the management-employee relations and the firm size. Although Kwoka (1980), Brown and Medoff (1989) and Idson (1990 have investigated the firm size in relation to job satisfaction, however, to our knowledge this issue together with management-employee relations has not been investigated before. Our hypothesis is that the management-employee relations are less satisfactory in large firms. Tables 2 and 3 report the results of unique questions in this survey. In these questions workers are requested to indicate whether they are frequently asked by the management on (a) staffing issues (b) pay issues and (c) health and safety at work. Asking these issues shows the concern of the management towards employees. An interesting result is that all of these variables are consistently negatively related to the firm size. Therefore, we accept the hypothesis that management-employee relations are less satisfactory in large firms.

[Table 2 and 3 about here]

Table 1 reports on another aspect of the management-employee relations. Although the questions asked are different in this table than in Table 2 the hypothesis we are testing is still the same as in Table 1, namely, the management-employee relations are less satisfactory in large firms. The Table 3 reports on the following question. Do the employees have discussed any of the indicated issues with the management during the past twelve months. These issues include how the employees are getting on with their jobs, their chances of promotion, training needs and pay. Among these variables, only the first one is negatively related to the firm size, indicating that in the larger firms the employees are less likely to be asked on how they are getting on with their job. This is expected because the issue is personal in nature and more likely to be asked in small firms. However, in large firms promotion prospects, training needs and pay issues are more likely to be discussed routinely. We also note that more educated employees are more likely to discuss chances of promotion, training needs and pay issues with their supervisors. Although not reported in this table, similarly, the employees in managerial and/or professional positions and in clerical occupations are more 
likely to discuss promotion, training and pay issues with their supervisors compared to the sales employees. For these and other results refer to Gazioglu and Tansel (2012).

\section{Management-Employee Relations and Job Satisfaction}

In this section we examine and the quality of the management-employee relationship and job satisfaction. Table 1 reports the means for the four different measures of job satisfaction at different firm sizes. They are satisfaction with influence over the job, satisfaction with the amount of pay, satisfaction with the sense of achievement and satisfaction with respect from supervisors. These indicators of job satisfaction have not been used before (excluding satisfaction with the amount of pay) in the literature except in Gazioglu and Tansel (2006). While the satisfaction with influence over job declines steadily as firm size increases. the other satisfaction measures indicate a nonlinear relationship to the firm size. Those who are very satisfied with their influence over their jobs decrease from 14.4 percent for firms with less than 25 employees to 10.4 percent for firms with 500 or more employees. Similarly, those who are very satisfied with the respect from their supervisors decrease from 19 percent for firms with less than 25 employees to 13.3 percent for firms with 500 or more employees. The other satisfaction measures indicate a nonlinear relationship to the firm size. Taking this into account we introduced a variable in the logarithm of the firm size in the job satisfaction regressions reported in Table 4 . The regressions in Table 4 are estimated with a maximum likelihood ordered probit technique. Table 4 gives the basic regression which is to be compared with the regression in Table 5.

The regressions in Table 5 are estimated with the maximum likelihood ordered probit technique and additionally include variables, which reflect the quality of the management-employee relations. Comparing Tables 4 and 5 we can assess the extent to which management-employee relationship variables can account for the effect of the firm size in job satisfaction regressions. We would like to see whether managerial relation variables can account for the lower levels of job satisfaction in larger firms. We note the negative 
and statistically significant coefficient estimates of log firm size in Table 4 for all of the four measures of job satisfaction which imply lower levels of job satisfaction in larger firms. This result confirms Clark (1996). When managerial relation variables are introduced as in Table 5 the coefficient estimates of log firm size in the job satisfaction regressions were driven to zero except in the satisfaction with sense of achievement. We conclude that observed lower level of job satisfaction in large firms can be attributed to the poor management-employee relations in larger firms. There are several sets of variables, which give the quality of the management-employees relations. In Table 5 the coefficient estimates of those workers who were frequently asked their views on staffing issues, pay issues, and health and safety at work were all positive and statistically significant in the four job satisfaction regressions. The coefficient estimates of the discussions with managers (during the past year) on how the employees are getting on with their jobs, their promotion, training needs and pay are all statistically insignificant. Furthermore, in these regressions the coefficient estimates of the management treating employees fairly are all positive and statistically significant. The variables describing the management-employee relations are jointly statistically significant. These results indicate that the communication of the management with employees and management's fair treatment of the employees all contribute positively towards job satisfaction of the employees and these aspects are better addressed in the small firms than in the large firms .

[Table 4 and 5 about here]

\section{Effects of Other Covariates}

In this section we report the results on covariates that are frequently discussed in the literature. First of all, as it is observed in the Tables 2 both genders are equally likely to be frequently asked about staffing and pay issues. However men are more frequently asked about health and safety at work than women. Table 3 shows that men have discussed more frequently than women how they are getting on with their jobs but less

frequently their chances of promotion. In contrast, there is no gender difference in their discussion of training needs and their pay issues with the management. Tables 4 and 5 indicate that women are more 
satisfied with their jobs than men by all indicators of job satisfaction such as satisfaction with influence over their jobs, with the amount of pay, with sense of achievement and with respect from supervisors. This is consistent with the findings in the literature in particular with the investigation of the gender differences in job satisfaction by Clark (1997) and Gazioglu and Tansel (2006).

With regards to the age of the respondents, Table 2 indicates that the employees are consulted more often on the staffing issues as they get more senior. However they are asked less frequently about pay issues and health and safety issues as they get older. Table 3 indicates that they are less likely to be consulted (during the past year) about how they are getting on with their jobs, chances of promotion, training needs and their pay as they get older. Tables 4 and 5 show that there is an U-shaped relationship between age and job satisfaction by all four measures of job satisfaction. This is consistent with the findings in the literature in particular the studies by Clark (1996), Clark et al. (1996) and Gazioglu and Tansel (2006).

The results in Tables 2 and 3 with respect to levels of education (lowest level of education is the base category) indicate that although "degree and post graduate and A level and $\mathrm{O}$ level holders" were not frequently asked their views on staffing issues they were less frequently consulted on pay and health and safety issues. Again, although the highly educated discussed (during the past year) how they are getting on with their jobs less frequently but their chances of promotion, training needs and pay less frequently. Tables 4 and 5 show that highly educated have lower levels of satisfaction than individuals with lower levels of education. This is a surprising but well established result in the findings of Clark (1996), Clark et al. (1996) Clark and Oswald (1996) and Gazioglu and Tansel (2006).

The results with regards to marital staus are not shown the tables of this paper but are available in the tables of Gazioglu and Tansel (2012). According to these results marital status does not affect the management- 
employee relationships except the negative influence on the health and safety issues. However, married employees are less satisfied with their jobs compared to those who are single in all four measures of job satisfaction. The findings in the literature on this point have been mixed. See Clark (1996) and Gazioglu and Tansel (2006). The results with regards to race indicate that mostly race does not matter in the managementemployee relationships. However, whites seem to be mostly satisfied and the blacks seem to be mostly dissatisfied (as it is also found by Clark, 1996) with their jobs compared to the Asians. The logarithm of the weekly income is sometimes positively and sometimes negatively related to the management-employee relationships. The log of weekly income mostly increases the all four measures of job satisfaction however more strongly the satisfaction with the amount of pay.

Providing training for their employees is an important investment which is expected to increase employee productivity reduce turnover. Tables 2 and 3 indicate that the availability of the training opportunities (whether less than 5 days or 5 days or more) during the past year improve the management-employee relationships in all cases except in the case of discussions of how the employees are getting on with their jobs. The effect of training opportunities on job satisfaction is not examined in the earlier literature except in Gazioglu and Tansel (2006). Tables 4 and 5 indicate that training availability during the past year leads to higher levels of job satisfaction compared to no training by all four measures of job satisfaction. This finding is consistent with the findings in Gazioglu and Tansel (2006) and with the hypothesis of Hamermesh (1977) that the job satisfaction is an increasing function of the training opportunities.

The other control variables included in the tables of this paper but not discussed here are employee health problems, job characteristics, occupation types, gender concentration and industrial composition. These results are available in Gazioglu and Tansel (2012). 


\section{Conclusions}

On exploring the management relationship with the employees we found the following: In large firms employees were less likely to be asked their views on staffing issues, pay issues, and health and safety at work. The variables on management-employee relations such as how the employees are getting on with their jobs, their chances of promotion, training needs and pay are also examined in relation to the firm size. Among these variables, only the question on how the employees are getting on with their job is negatively related to the firm size implying that this is not a concern in the large firms. However, the promotion prospects, training needs and pay issues are more likely to be discussed routinely in large firms. Employees are less satisfied with their jobs in large firms in the absence of controls for the quality of managementemployee relationships. However, when controls for management-employee relationships are introduced the effects of firm size on various measures of job satisfaction disappeared completely implying that management-employee relationships are weaker in large firms than in the small firms.

The results in this paper support the following propositions. First, the management-employee relationships are less satisfactory in large firms. However, there is also evidence that large firms are trying to compensate for their size by providing regular discussions of promotion possibilities, training needs and pay issues. Second,the observed lower levels of job satisfaction in the large firms may be due to weak management-employee relationships. These results have important policy implications for the business managers in particular in the large firms in the area of management-employee relationships. Improving the management-employee relations in large firms will not only increase employee satisfaction in several respects but it will also increase productivity and reduce turnover. Achieving these is important from the point of view of the managers. The validity of the conclusions of this paper could be checked with an updated data. However we do not expect much change in the conclusions since human relations within the organizations change only slowly if at all. The analysis could be done in other countries in order to check 
the validity of conclusions in different cultural settings. These are deferred to future studies depending on the availability of appropriate data.

Notes:

[1]Kwoka (1980) explains higher wages in larger firms to be the compensation for the lower worker satisfaction. However, Dunn $(1980,1986)$ suggest that higher pay in larger firms could not be fully explained by lower worker satisfaction. Brown and Medoff (1989) and Belfield and Wei (2004) gave other possible explanations of the positive relationship between wages and employer size. These include the possibility that larger firms may hire higher quality workers, may use higher wages to preclude unionization and are less able to monitor their workers. 


\section{References:}

Akerlof, GA, Rose, AK and Yellen JL (1988), "Job Switching and job satisfaction in the US labour market”. Brooking Papers on Economic Activity, Vol. 2, pp495-582.

Belfield, C. R. and Harris, R. D. F. (2002), "How well do theories of job matching explain variations in job satisfaction across education levels? Evidence for UK graduates”, Applied Economics, Vol.34, pp. 535-48.

Belfield, C. R. and X. Wei (2004), "Employers Size-Wage Effects: Evidence from Matched EmployerEmployee Survey Data in the UK" Applied Economics, Vol.36, pp185-193.

Bender, K: and P. Sloane (1998), "Job Satisfaction, Trade Unions and Exit-Voice Revised" Industrial and Labor relations Review, pp.51, pp.222-240.

Bender, K. A. and J. S. Haywood (2006), "Job Satisfaction of the Highly Educated: The Role of Gender, Academic Tenure, and Comparison Income" Scottish Journal of Political Economy, Vol.53, No:2, pp.253279.

Bockerman, P. and Ilmakunnas, P. (2006), "Do Job Disamenities Raise Wages or Ruin Job Satisfaction", International Journal of Manpower, Vol. 27 No.3, pp. 290-302.

Brown, D. and McIntosh, S. (2003), "Job satisfaction in the low wage service sector," Applied Economics, Vol. 35, pp.1241-54.

Brown C. and J. Medoff (1989), "The Employers Size -Wage effect" Journal of Political Economy, Vol. 97, pp. 1027-1059.

Clark, A. E.(1996) "Job Satisfaction in Britain” British Journal of Industrial Relations, Vol.34 No. 2 , pp.189-217.

Clark, A. E.(1997), “Job satisfaction and Gender: Why are Women so Happy at Work?” Labour Economics, Vol. 4, pp.341-372.

Clark A. E. (1999), "Are wages habit-forming? Evidence from micro data.” Journal of Economic Behavior and Organization, Vol.39, pp.179-200.

Clark, A. E. and Oswald, A. J. (1994), 'Unhappiness and unemployment”, Economic Journal, Vol. 104, pp.648-59.

Clark, A. E. and Oswald, A. J. (1996), "Satisfaction and comparison |income", Journal of Public Economics, Vol. 61, pp.359-81.

Clark, A. E., Oswald, A. and Warr, P. (1996), “Is job satisfaction u-shaped in age?” Journal of Occupationa land Organizational Psychology, Vol.69, pp.57-81.

Clark, AE, Georgellis, Y and Sanfey, P (1998), "Job satisfaction, wage changes, and quits". Research in Labour Economics, Vol. 17, pp.95-121. 
Drydakis,N. (2012), "Health Impaired Employees Job satisfaction New Evidence from Athens, Greece" Applied Economics Letters, Vol.19 no.8, pp.789-793.

Dunn, L. F. (1980), “The Effects of Firm and Plant Size on Employee Well-Being" in The Economics of Firm Size, Market Structure and Social Performance (Ed.) J. J. Siegfried, Federal Trade Commission, Washington DC.

Dunn, L. F. (1986), "Work Disutility and Compensating Differentials: Estimation of Factors in The Link Between Wages and Firm Size", Review of Economics and Statistics, Vol. 68, pp. 67-73.

Freeman, RN (1978), "Job satisfaction as an economic variable". American Economic Review, Vol. 68, No.2, pp.135-141.

Gazioglu, S. and A. Tansel (2006), 'Job Satisfaction in Britain: Individual and Job Related Factors' Applied Economics, Vol. 8, pp.1163-1171.

Gazioglu, S. and A. Tansel (2012), "Managerial Attitudes Towards Employees, Firm Size and Job Satisfaction in Britain," ERC Working Paper,Ankara: Department of Economics Middle East Technical University.

Haile, G. A. (2010), "Workplace Job Satisfaction in Britain:Evidence from Linked Employer-Employee Data" Institute for the Study of Labor (IZA) Discussion Paper No. 4101,Bonn.

Hamermesh, D. (1977), “Economic Aspects of Job Satisfaction” In: O. Ashenfelter and W. Oates (eds.) Essays in Labor market Analysis (pp.53-72),New York: John Wiley.

Hamermesh, D. (2000), “The Changing Distribution of Job Satisfaction” Journal of Human Resources, 36, pp.1-30.

Hinks, T. (2009), "Job Satisfaction and Employment Equity in South Africa" Journal of African Economies, Vol.19 No. 2, pp.237-255.

Iaffaldano, M. T and P. M. Muchinsky (1985), "Job Satisfaction and Job Performance:

A Meta-Analysis" Psychological Bulletin, Vol. 97 No2, 251-273.

Idson, T. L. (1990), "Firm size, job satisfaction and the structure of work" Applied Economics, Vol.22, pp.1007-1018.

Kwoka, J. E. Jr. (1980) "Firm Size, Wages, and Job Satisfaction: the Tradeoffs", in The Economics of Firm Size, Market Structure and Social Performance, J. J. Siegfield (ed.) Federal Trade Commission, Washington, DC.

Lévy-Garboua, L., Montmarquette, C., and Simonnet, V. (2007), "Job Satisfaction and Quits: Theory and Evidence from the German Socioeconomic Panel" Labour Economics, Vol.14, pp.251-268.

Linz, S. J.(2003), “Job Satisfaction among Russian Workers”, International Journal of Manpower, Vol 23 No.6, pp. 626-652. 
Marlow, S., D. Patton and M. Ram (2004): Managing Labor in Small Firms, Routledge Studies in Small Business, London.

Rose, M. (2000): 'How Far Can I Trust It? Job Satisfaction Data in the WER98 Employee Survey' Working Paper no.6 ESRC Future of Work Program, Swindox: ESRC.

Rose, M. (2005), "Job Satisfaction in Britain: Coping with Complexity". British Journal of Industrial Relations, 43, 455-467.

Scherer, F. M. (1976), 'Industrial Structure, Scale Economies and Worker Alienation', in Essays in Honor of Joe S. Bain, R. T Masson and P. D. Qualls (eds.), Ballinger.

Sloane, P. and M. Ward (2001): 'Cohort Effects and Job satisfaction of Academics' Applied Economics Letters, 8, pp.786-791.

Stafford, F. P. (1980), 'Firm Size, Workplace Public Goods, and Worker Welfare', in The Economics of Firm Size, Market Structure and Social Performance (Ed.) J. J. Siegfried, Federal Trade Commission, Washington DC.

Uppal, S. (2005), ' Disability, Workplace Characteristics and Job Satisfaction” International Journal of Manpower, 26(4), pp.336-349.

Yousef, D. (1998), ‘ Satisfaction with Job Security as a Predictor of Organizational Commitment and Job Performance in a Multicultural Environment' International Journal of Manpower, 19(3), pp.184-194. 


\section{TABLES}

Table 2: Maximum Likelihood Probit Estimates of the Relationship with the Management I : Workers' View

Were You Frequently Asked Your Views on the Following Staffing Issues

\begin{tabular}{ccc} 
Coefficient & t-Ratio & \\
\cline { 1 - 1 }-0.081 & & 7.95 \\
0.023 & & 0.79 \\
1.552 & & 1.86 \\
-0.119 & & 1.19
\end{tabular}

Level of Education:

Degree+Post Graduate

A Level+O Level

Married

Health Problems

$\underline{\text { Race: }}$

White

Black

Job Characteristics:

Log Weekly Income

Log Hours of Work

Union Member

Occupation:

Managerial/Professional

Clerical

Gender Concentration:

Mostly Men $\left(\times 10^{-2}\right)$

Industrial Composition:

Manufacturing

Electricity+Gas+Water

Construction

Transportation

Financial Services

Education Sector $\left(\times 10^{-2}\right)$

Health Sector

Training:

Less Than 5 Days

5 Days or More

Constant

$\begin{array}{ll}-0.690 & 1.52 \\ -0.056 & 1.46 \\ -0.044 & 1.54 \\ -0.099 & 1.76\end{array}$

0.166

0.057

1.98

0.42

$\begin{array}{rr}0.332 & 9.33 \\ 0.037 & 0.82 \\ -0.143 & 5.41\end{array}$

$\begin{array}{lr}0.481 & 10.63 \\ 0.053 & 1.32\end{array}$

$-0.181$

5.55

$-0.121$

$-0.130$

$-0.202$

$-0.025$

$-0.204$

0.175

0.035

2.84

0.207

0.370

$-0.647$
Pay Issues

$\underline{\text { Coefficient }}$ t-Ratio $^{\mathrm{a}}$

$-0.060$

$-0.031$

$-2.950$

0.380

$-0.049$

$-0.106$

$-0.044$

$-0.004$

5.23

0.96

3.34

3.62

0.98

2.58

1.35

0.06

$-0.003$

$-0.129$

0.03

0.84

0.215

0.044

$-0.209$

5.53

0.88

6.87

0.175

$-0.173$

3.66

4.19

0.149

$-0.085$

4.59

3.23

$-0.032$

0.89

$-0.034$

1.36

$\begin{array}{rr}0.058 & 1.32 \\ -0.091 & 1.23 \\ -0.083 & 1.24 \\ 0.016 & 0.27 \\ 0.060 & 1.41 \\ -0.251 & 4.62 \\ -0.053 & 1.05\end{array}$

0.072

0.198

1.990
0.117

0.344

0.238

$-0.117$

$-0.232$

$-0.074$

0.228

0.324

0.553
2.10

3.22

0.46

5.29

3.94

0.82
2.24

5.10

9.05
3.79

7.43

5.38

2.73

7.35

2.10

6.92

16.84
$-0.454$ 
-Log Likelihood

Chi-Squared

Number of Observations
6743

1489

24400
5072

504

24355
12450

1152

24579 
Table 3: Maximum Likelihood Probit Estimates of the Relationship with the Management ll: Workers' View

During the Last Twelve Mohths

Have You Discussed Any of the Following with Your Supervisors How Are You

Getting on

With Your Job

$\underline{\text { Coefficient }}_{\text {t-Ratio }^{a}}$
Your Chances

of Promotion

$\underline{\text { Coefficient }} \underline{\text { t-Ratio }}$

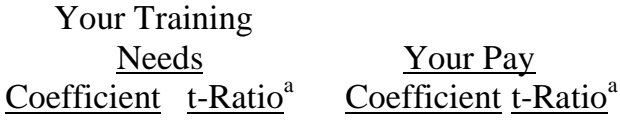

Log Firm Size

Male

Age (x10-2)

Age Square $\left(\times 10^{-3}\right)$

Level of Education:

Degree + Postgraduate

A level+O level

Married

Health Problems

$\underline{\text { Race: }}$

White

Black

Job Characteristics:

Log Weekly Income

Log Hours of Work

Union Member

Occupation:

Managerial/Professional

Clerical

Gender Concentration:

Mostly Men

Industrial Composition:

Manufacturing

Electricity+Gas+Water

Construction

Transportation

Financial Services

Education Sector

Health Sector

Training:

Less than 5 Days

5 Days or More

Constant

- Log Likelihood

Chi-Squared (25)

Number of Observations

$-0.048$

0.086

0.615

0.073

\subsection{9}

4.17

1.14

1.10

$-0.166$

$-0.178$

0.004

$-0.102$

5.08

7.11

0.22

2.71

$-0.100$

0.018

1.84
0.20

0.016

$-0.100$

2.17

4.64

$-0.578$

1.04

0.059

0.87

$\begin{array}{ll}0.075 & 2.22 \\ 0.106 & 4.02 \\ 0.014 & 0.69 \\ 0.124 & 3.28\end{array}$

0.184

0.194

0.004

0.008

4.69

6.08

0.15

0.19

2.68

0.028

0.023

0.948

$-0.033$

2.82

0.82

1.13

3.14

\section{$-0.210$}

8.80

$-0.062$

0.101

2.07

5.33

0.079

1.40

1.29

-0.100
-0.143

1.66
1.41

0.226

$-0.521$

2.69

0.118

$\begin{array}{rr}0.072 & 2.93 \\ -0.040 & 1.30 \\ 0.090 & 4.45\end{array}$

0.118

0.139

4.18

3.73

$-0.550$

2.30

0.219

$-0.229$

$-0.292$

6.09

4.58

10.74

$-0.373 \quad 12.18$

0.120

3.78

0.180

4.99

0.134

4.53

0.33

0.085

7.56

$0.145 \quad 5.73$

4.12

0.016

2.17

$-0.052$

2.01

$-0.050$

1.62

0.150

5.10

$-0.056$

2.37

$-0.041$

$-0.047 \quad 1.04$

0.133

$-0.142$

$-0.031$

0.086

$-0.286$

$-0.229$

1.23

0.015

0.119

0.38

$0.211 \quad 4.98$

$\begin{array}{ll}0.151 & 3.89\end{array}$

$-0.160$

5.69

$-0.183$

4.47

2.62

2.79

$-0.830$

0.009

0.206

2.88

7.28

$-0.372$

$-0.260$

$0.341 \quad 11.08$

$\begin{array}{ll}-0.593 & 30.45 \\ -0.910 & 35.46 \\ 1.815 & 13.65\end{array}$

$\begin{array}{ll}0.343 & 16.58\end{array}$

0.352

0.530

14.51

18.50

$-1.211 \quad 8.90$

$-2.500$

14103

902

24894
14859
4701

24894
10533
1341

24894
$0.514 \quad 14.76$

$-3.980 \quad 17.85$

6752

1823

24894 


\section{Table 1: Variable Means for Job Satisfaction, Firm Size and Management Relations (\%)}

\begin{tabular}{|c|c|c|c|c|c|c|c|c|}
\hline \multirow[b]{2}{*}{ Firm Size: } & \multicolumn{2}{|c|}{$\frac{\text { Satisfaction with }}{\text { Influence Over Job }}$} & \multicolumn{2}{|c|}{$\frac{\text { Satisfaction with }}{\text { Amount of Pay }}$} & \multicolumn{2}{|c|}{$\begin{array}{c}\text { Satisfaction with } \\
\text { Sense of Achievement }\end{array}$} & \multicolumn{2}{|c|}{$\begin{array}{r}\text { Satisfaction wi } \\
\text { Respect from Sup }\end{array}$} \\
\hline & $\underline{\text { Satisfied }}$ & $\begin{array}{c}\text { Very } \\
\text { Satisfied } \\
\end{array}$ & $\underline{\text { Satisfied }}$ & $\begin{array}{c}\text { Very } \\
\text { Satisfied }\end{array}$ & $\underline{\text { Satisfied }}$ & $\begin{array}{c}\text { Very } \\
\text { Satisfied }\end{array}$ & $\underline{\text { Satisfied }}$ & $\begin{array}{c}\text { Very } \\
\text { Satisfie }\end{array}$ \\
\hline Less than 25 employees & 49.9 & 14.4 & 33.1 & 3.3 & 51.9 & 18.1 & 44.4 & 19.0 \\
\hline 25-99 employees & 47.9 & 11.8 & 31.9 & 3.4 & 49.9 & 16.0 & 44.5 & 15.5 \\
\hline 100-199 employees & 46.1 & 11.9 & 31.1 & 3.7 & 47.9 & 14.0 & 43.6 & 12.6 \\
\hline 200-499 employees & 46.5 & 11.2 & 33.4 & 3.3 & 47.7 & 13.7 & 43.7 & 12. \\
\hline 500 or more employees & 47.0 & 10.4 & 32.7 & 3.7 & 48.3 & 14.1 & 43.3 & 13. \\
\hline
\end{tabular}

Relations with Supervisors/Line Managers:

During the Past Year Have You Discussed the Following with Your Managers:

How You are Getting

on with your job

$\begin{array}{llllll}43.4 & 10.9 & 30.4 & 3.4 & 46.2 & 13.7\end{array}$

$39.8 \quad 12.1$

Your Chances of

Promotion

49.3

$11.0 \quad 34$

$\begin{array}{llll}34.6 & 3.5 & 50.8 & 15.8\end{array}$

$\begin{array}{lll}5.8 & 47.8 & 14.9\end{array}$

Your Training Needs

51.4

13.1

33.6

3.5

52.4

16.4

48.9

16.7

Your Pay

53.8

15.1

$32.4 \quad 3.6$

52.5

18.4

48.0

19.4

Were You Frequently Asked Your Views on the Following?

Staffing Issues

Pay Issues

Health/Safety at Work

\begin{abstract}
$54.8 \quad 26.9$
\end{abstract}
52.6

29.5

55.2

\begin{abstract}
44.5
\end{abstract}
$8.3 \quad 51.6$

28.2

47.4

9.9

38.9

$6.6-52.2-25.8$

52.2

28.7

Would You Say that the Managers Here are very Good at

Treating Employees Fairly 54.0

30.6

45.5

10.6

$48.5 \quad 37.8$

42.3

49.4

How would You Describe the Relations Between Managers and Employees Here?

Very Good

$55.5 \quad 28.2$

44.1

9.1

$52.2 \quad 34.9$

47.0

45.7 
Table 4: Maximum Likelihood Ordered Probit Estimates of Job Satisfaction when Relations with Management Variables are Excluded

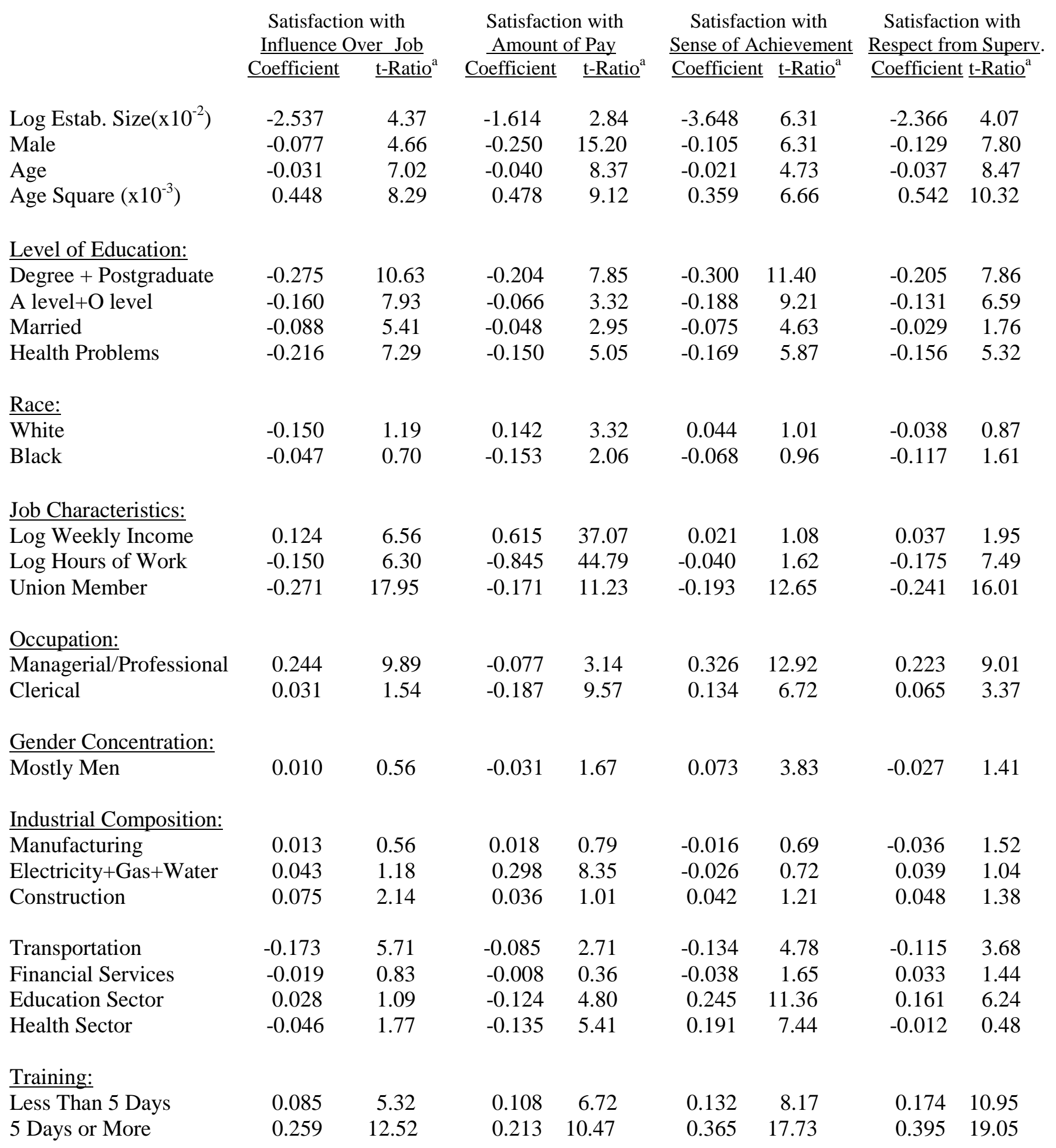




\begin{tabular}{|c|c|c|c|c|c|c|c|c|}
\hline & $\begin{array}{l}\text { Satisfacti } \\
\text { Influence }\end{array}$ & $\begin{array}{l}\text { with } \\
\text { ver Job }\end{array}$ & $\begin{array}{r}\text { Satisfact } \\
\text { Amount } \\
\end{array}$ & $\begin{array}{l}\text { on with } \\
\text { of Pay }\end{array}$ & $\begin{array}{r}\text { Satisfact } \\
\text { Sense of A }\end{array}$ & $\begin{array}{l}\text { tion with } \\
\text { chievement }\end{array}$ & $\begin{array}{r}\text { Satisfac } \\
\text { Respect f }\end{array}$ & $\begin{array}{l}\text { n with } \\
\text { n Superv. }\end{array}$ \\
\hline & Coefficient & $\underline{\text { t-Ratio }}^{a}$ & Coefficient & $\underline{\text { t-Ratio }}^{\mathrm{a}}$ & Coefficien & t ${\underline{\mathrm{t}-\text { Ratio }^{\mathrm{a}}}}^{\mathrm{a}}$ & Coefficie & t-Ratio $^{a}$ \\
\hline Constant & 2.570 & 23.10 & 1.782 & 17.26 & 2.101 & 19.00 & 2.577 & 24.16 \\
\hline Treshold Parameters: & & & & & & & & \\
\hline $\begin{array}{l}M(1) \\
M(2)\end{array}$ & $\begin{array}{l}0.880 \\
1670\end{array}$ & 58.01 & 0.913 & 94.12 & 0.694 & $\begin{array}{l}53.96 \\
0512\end{array}$ & 0.600 & 59.04 \\
\hline $\begin{array}{l}\text { M (2) } \\
\text { M (3) }\end{array}$ & $\begin{array}{l}1.670 \\
2.132\end{array}$ & 100.35 & 1.607 & 135.73 & 1.396 & 95.13 & 1.226 & 101.11 \\
\hline M (3) & 3.133 & 165.38 & 3.142 & 169.50 & 2.853 & 166.71 & 2.563 & 170.69 \\
\hline - Log Likelihood & 319 & & 340 & & 3180 & & & 807 \\
\hline Chi-Squared (25) & 11 & & 22 & & 161 & & & 540 \\
\hline Number of Observations & 245 & & 244 & & 2436 & & & 208 \\
\hline
\end{tabular}


Table 5 : Maximum Likelihood Ordered Probit Estimates of Job Satisfaction when Management Relations Variables are Included

Satisfaction with

Influence Over Job

Coefficient $\underline{\text { t-Ratio }}^{\text {a }}$
Satisfaction with

Amount of Pay

Coefficient t-Ratio $^{\text {a }}$
Satisfaction with

Sense of Achievement Respect from Superv. Coefficient t-Ratio $^{\text {a }}$ Coefficient t-Ratio ${ }^{\mathrm{a}}$

Log Estab. Size (x10 $\left.{ }^{-2}\right)$
Male

Age

Age Square $\left(\times 10^{-3}\right)$

Level of Education:

Degree+Postgraduate

A Level+0 Level

Married

Health Problems

Race:

White

Black

Job Characteristics:

Log Weekly Income

Log Hours of Work

Union Member

Occupation:

Managerial/Professional

Clerical

Gender Concentration:

Mostly Men

Industrial Composition:

Manufacturing

Electricity+Gas+Water

Construction

Transportation

Financial Services

Education Sector

Health Sector

$-0.146$

$-0.102$

0.24

$-0.024$

0.356

5.91

5.13

6.24

$-0.229$

8.39

$-0.132$

$-0.887$

$-0.219$

6.16

5.23

7.06

$-0.063$

$-0.073$

1.43

1.03

$\begin{array}{rr}0.143 & 7.11 \\ -0.155 & 6.10 \\ -0.239 & 15.07\end{array}$

0.665

$-0.875$

$-0.146$

38.06

45.07

9.23

0.176

6.77

1.72

$-0.116$

$-0.193$

4.56

9.46

$-0.032$

1.65

0.023

1.21

0.035

0.053

\subsection{3}

1.41

0.044

0.327

0.041

1.84

$-0.600$

$-0.145$

4.60

0.012

$-0.171$

$-0.183$

\subsection{1}

8.93

1.13

1.75

0.49

0.008

0.31

2.97

$\begin{array}{ll}0.019 & 1.14 \\ 0.274 & 9.42\end{array}$

0.086

0.144

5.08

6.60

Relations with Management:

Were You Frequently Asked Your Views on the Following:

$\begin{array}{llll}\text { Staffing Issues } & 0.274 & 9.42 & 0.143\end{array}$

Pay Issues

0.240

6.68

0.275

$0.261 \quad 13.36$

0.146
5.10

8.00

7.92
Health/Safety at Work
$-0.016$

$-0.122$

$-0.011$

2.75

7.15

2.48

0.242

4.37

$-0.258$

$-0.158$

9.51

7.46

$-0.0724 .33$

$-0.173 \quad 5.84$

0.900

$-0.167$

1.46

$-0.024$

9.64

0.410

5.34

7.35
0.029

$-0.077$

0.66

1.05

$-0.056$

$-0.124$

1.22

1.61

$\begin{array}{rrrr}0.035 & 1.75 & 0.051 & 5.52 \\ -0.043 & 1.71 & -0.191 & 7.62 \\ -0.152 & 9.69 & -0.190 & 11.83\end{array}$

$0.278 \quad 10.72$

0.150

5.72

0.144

7.02

0.079

3.86

0.081

4.18

$-0.015$

0.78

0.008

$-0.030$

0.31

0.79

0.015

0.60

0.336

0.94

$-0.109$

3.46

$-0.030$

1.29

10.95

0.293

6.54

0.061

1.54

$0.050 \quad 1.36$

$-0.075 \quad 2.33$

$0.037 \quad 1.56$

0.173

0.153

5.57

$-0.038$

1.41

$\begin{array}{lr}0.067 & 3.95 \\ 0.222 & 10.20\end{array}$

0.061

3.54

0.22

$\begin{array}{lr}0.104 & 3.62 \\ 0.133 & 3.81 \\ 0.271 & 14.18\end{array}$

0.220

7.41

$0.271 \quad 14.18$

$0.287 \quad 14.73$
$0.175 \quad 7.83$ 


$\begin{array}{cccc}\begin{array}{c}\text { Satisfaction with } \\ \text { Influence Over Job }\end{array} & \begin{array}{c}\text { Satisfaction with } \\ \text { Amount of Pay }\end{array} & \begin{array}{c}\text { Satisfaction with } \\ \text { Coefficient }\end{array} & \begin{array}{c}\text { Satisfaction with } \\ \text { Senstio of Achievement }\end{array}\end{array}$

During the Past Year Have You Discussed the Following with Your Manager:

$\begin{array}{lcccccccc}\begin{array}{l}\text { How You are Getting on } \\ \text { with Your Job }\end{array} & 0.169 & 0.64 & -0.008 & 0.02 & -0.326 & 1.17 & 0.233 & 0.54 \\ \begin{array}{l}\text { Your Chances of Promotion } \\ \text { Your Training Needs }\end{array} & 0.246 & 0.94 & 0.040 & 0.12 & -0.234 & 0.84 & 0.467 & 1.08 \\ \text { Your Pay } & 0.295 & 1.13 & -0.039 & 0.14 & -0.192 & 0.69 & 0.528 & 1.22 \\ \text { Y } & 0.303 & 1.16 & -0.190 & 0.55 & -0.145 & 0.52 & 0.550 & 1.27\end{array}$

Would You Say that the Managers are very Good at

$\begin{array}{lrrrrrrrr}\text { Treating Employees Fairly } & 0.420 & 15.35 & 0.364 & 14.09 & 0.435 & 16.41 & 0.716 & 25.32 \\ \text { Constant } & 1.950 & 6.79 & 1.325 & 3.68 & 1.932 & 6.43 & 1.710 & 3.83\end{array}$

$\underline{\text { Treshold Parameters: }}$

\begin{tabular}{|c|c|c|c|c|c|c|c|c|}
\hline M (1) & 0.908 & 56.69 & 1.000 & 92.28 & 0.709 & 53.74 & 0.635 & 58.03 \\
\hline $\mathrm{M}(2)$ & 1.737 & 98.34 & 1.654 & 132.92 & 1.442 & 95.39 & 1.317 & 100.14 \\
\hline M (3) & 3.301 & 161.60 & 3.269 & 159.68 & 2.981 & 166.00 & 2.866 & 167.14 \\
\hline - Log Likelihood & \multicolumn{2}{|c|}{28632} & \multicolumn{2}{|c|}{31396} & \multicolumn{2}{|c|}{30027} & \multicolumn{2}{|c|}{29588} \\
\hline Chi-Squared (34) & \multicolumn{2}{|c|}{3383} & \multicolumn{2}{|c|}{3539} & \multicolumn{2}{|c|}{3539} & \multicolumn{2}{|c|}{5966} \\
\hline Likelihood Ratio Test & \multicolumn{2}{|c|}{3350} & \multicolumn{2}{|c|}{2742} & \multicolumn{2}{|c|}{1856} & \multicolumn{2}{|c|}{2878} \\
\hline Number of Observations & \multicolumn{2}{|c|}{22900} & \multicolumn{2}{|c|}{23109} & \multicolumn{2}{|c|}{23706} & \multicolumn{2}{|c|}{22769} \\
\hline
\end{tabular}

Notes:

The likelihood ratio test tests for the joint significance of the variables describing management-employee relationships. In each case, the statistic is distributed as a chi-square with nine degrees of freedom and is significant at the one percent level. The null hypothesis that the variables describing management-employee relationships are jointly zero is rejected in each case. 